Research, part of a Special Feature on Understanding the Vulnerability and Sustainability of Urban Social-Ecological Systems in the Tropics: Perspectives from the City of San Juan

\title{
Multiple pathways to sustainability in the city: the case of San Juan, Puerto Rico
}

Tischa A. Muñoz-Erickson ${ }^{1}$

\begin{abstract}
I examined the multiple visions of the future of the city that can emerge when city actors and organizations reconfigure themselves to address sustainability. In various cities worldwide, novel ideas, initiatives, and networks are emerging in governance to address social and ecological conditions in urban areas. However, cities can be contested spaces, bringing a plurality of actors, network configurations, preferences, and knowledge that shape the politics over desirable pathways for future development. I used the knowledge-action systems analysis (KASA) approach to examine the frames and knowledge systems influencing how different actors involved in the land governance network of the city of San Juan constructed visions for the future of the city. Results revealed four visions for the city coexisting in San Juan. Although sustainability is a goal that cuts across all four visions, they each optimized distinct dimensions of the concept. The contrasts in visions can be explained in part by competing frames of the urban social-ecological system and power asymmetries in the multiple knowledge systems coexisting in the city. I discussed the theoretical, methodological, and practical implications of the politics of sustainability for adaptive urban governance research and practice. The KASA approach can serve as a window into the adaptive capacity of the city by disentangling the competing ways that actors 'see' and 'know' the urban social-ecological systems. Most importantly, this approach offers a way of appraising sustainable pathways by revealing either the extent to which dominant social structures and cognitive patterns are being reinforced, or whether opportunities for innovative and transformative approaches are emerging in the city.
\end{abstract}

Key Words: adaptive capacity; adaptive governance; frames; knowledge-action systems; networks; San Juan; sustainable pathways; transformation; urban social-ecological systems; visions

\section{INTRODUCTION}

I examined the multiple visions of the future of the city that can emerge when city actors and organizations reconfigure themselves to address sustainability. In various cities worldwide, novel ideas, initiatives, and networks are emerging in governance to address social and ecological conditions of urban areas (Moore 2007, Svendsen and Campbell 2008, Wiek and Iwaniec 2013). In some contexts, however, multiple sectors of the city can have competing visions about the future of the city, bringing into focus the role of the politics of sustainability in urban governance. The city of San Juan, Puerto Rico, for instance, has a land-use plan that includes sustainable development goals. New organizations and networks are also emerging to revitalize urban cores and improve environmental conditions. At the same time, modern urban development models, which have put people at risk in the past, e.g., to flooding, continue to dominate the economic sector and much of state planning. Underlying these efforts are different ways of seeing the city and expectations of how San Juan should develop in the future (Muñoz-Erickson 2014).

The central question of my research, i.e., how are multiple visions of the future, or pathways to sustainability, emerging and constructed in politicized urban contexts, has theoretical and practical implications for cities in general. As social-ecological systems (SES), cities are heterogeneous, multiscalar, and multiinstitutional systems (Grimm et al. 2008, Pickett et al. 2008), as well as highly networked and contested spaces (Ernstson et al. 2010). Cities bring a plurality of actors, network configurations, preferences, and knowledge that shape the politics over desirable, or undesirable, pathways of the future development (Healey et al. 2003). It is crucial to understand how the politics of sustainability influence conditions for adaptive governance in cities, given that more than half the world's populations live in urban areas (United Nations 2007).

My aim is to explore how the emergence of multiple pathways of sustainability relates to the ability of governance actors and networks to build adaptive and transformation capacity in cities like San Juan. I begin by discussing the importance of understanding the socio-political and cultural dimensions of defining future pathways for sustainability. I then present the knowledge-action systems analysis (KASA) approach (MuñozErickson 2014) as a tool to understand how visions are constructed in a multiactor governance network, followed by methods and findings section. In the discussion I present the theoretical, methodological, and practical implications of the study and conclude with a discussion of limitations and directions for future research.

\section{THEORETICAL BACKGROUND}

Various scholars consider adaptive governance an ideal approach to build adaptive and transformation capacity for the sustainability of SES (Olsson et al. 2004, Folke et al. 2005). Adaptive governance can be defined here as creating the conditions for ordered rule and coordination by which actor/ networks share power to resolve trade-offs, collaborate across scales and institutional levels, and foster transformation toward more sustainable system states (Folke et al. 2005, Olsson et al. 2006). A central goal of adaptive governance is to build adaptive capacity. Adaptive capacity is the ability of individuals and groups to cope with, manage, or adjust to some changing condition or risk and take advantage of opportunities for effective ecological and social resource use that build system resilience (Brooks et al. 
2005, Smit and Wandel 2006). Common property theorists have long established that locally evolved institutional arrangements, i.e., the rules, norms, and strategies that govern social interactions, are crucial to sustain resources successfully and to build adaptive capacity in SES. These arrangements should include feedback and monitoring mechanisms, information about resource condition, adequate infrastructure, and polycentric institutions that span multiple organizational levels (Dietz et al. 2003, Ostrom 2009).

Typically missing from these frameworks, however, is a critical examination of the socio-political and cultural factors that shape how humans actively construct, adapt, and frame future development pathways (Leach et al. 2010, Smith and Stirling 2010, Pelling and Manuel-Navarrate 2011). How a desirable or undesirable pathway for a SES is conceived and defined among different social groups is rarely questioned. For instance, the adaptive governance framework is grounded on perspectives of ecosystem resilience, the idea that an ecosystem has the capacity to tolerate disturbance without degrading into less desirable states (Holling 1973). Resilience and adaptive governance perspectives acknowledge that SES can have multiple stable states and that purposeful action can facilitate SES transformation from a vulnerable state to a preferred novel system configuration (see Olsson et al. 2006). However, the dominance of ecological epistemologies in much of the SES literature brings an implicit assumption that consensus can be reached around a desired 'natural' state (Leach 2008). This bias toward ecosystem management principles sometimes results in leaving out other desired states that address broader goals of sustainability, such as poverty reduction and social justice (Leach 2008), or which produce emergent properties, i.e., new ecosystems services, which are being observed in novel ecosystems and cities (Lugo 2009, Ernstson 2013).

Several urban studies demonstrated how the transformational capacity of cities is entangled in the complex politics and expectations of urban governance. Two key studies on urban regeneration by Healey et al. 2003 and Hommels 2008 concluded that the institutional capacity of new actors, networks, and initiatives to shape transformation processes can be shattered when they encounter embedded power dynamics, frames, and ways of thinking, i.e., what Healey terms institutional inheritance. Thus, although cities are often considered seedbeds of creativity and innovation, if these tensions are left unexamined they may lead to obduracy and inflexibility rather than transformation (Hommels 2008). In a study examining the production and valuation of ecosystem services in cities, Ernstson (2013) found that what is known and valued about the city as an SES is a result of political dynamics in which knowledge is constructed and certain ways of knowing may be silenced. In contrast, a study of cities known for their sustainability efforts, Austin, Curitiba, and Frankfort, showed that cities can be successful in charting and implementing sustainability precisely because governance actors were aware about the way that urbanites engaged in constructing narratives about sustainability that fit their particular context (Moore 2007). In other words, instead of following an abstract, objective model of sustainability, these cities addressed the local politics of sustainability and were able to resolve competing narratives and move forward with sustainable pathways that worked for their cities. These studies also show the value of applying critical and interpretative approaches to examining the socio-political and cultural factors that play a role in the adaptive and transformational capacity of cities.

An important part of building conditions for urban adaptive governance therefore involves more explicit attention to the various ways that future pathways for sustainability are being constructed for cities. As Leach et al. (2010) argued, dynamic contexts interacting with dynamic systems over time and space means that there will be available multiple, possible routes for sustainability. Which pathway for adaptation is chosen and with what results is a wider political choice, judged in terms of normative, not just objective qualities. Based on this context, I adopted a normative definition of sustainability, which refers to the deliberative process, not just outcomes, of defining and maintaining 'specified qualities' of human well being, social equity, and environmental health over indefinite periods of time (Leach et al. 2010). This definition provides a way to evaluate pathways of sustainability with respect to the collective social perceptions and expectations as produced from the networked interactions of actors in cities.

I used the knowledge-action systems analysis (KASA), an interdisciplinary analytical approach, which incorporates concepts and tools from the fields of interpretative policy analysis, science and technology studies (STS), and social networks to analyze governance systems. Knowledge-action systems analysis was developed to expose and disentangle the political (visions and frames), epistemological (knowledge systems), and structural (networks) dynamics of governance actors as they advance specific policies, decisions, and actions related to sustainability. Knowledge-action systems refer to the formal and informal networks of individuals and organizations in which knowledge, ideas, and strategies for sustainability are being produced, evaluated, and validated (Muñoz-Erickson 2014). Visions here are the expectations and desires that social groups have for the future (Wiek and Iwaniec 2013) and which reflect those specified qualities of sustainability being constructed and prioritized. Understanding visions involves both how people perceive and produce knowledge about the world, i.e., knowledge systems, and frames reflect how people understand and represent their interpretations of reality (Goffman 1974).

The tools of social network analysis (SNA) are used in KASA to cast a wide net of governance actors, i.e., nodes, and examine their linkages, such as information flows (Wasserman and Faust 1994). This allows an expanded, systems-based approach to describe knowledge-action systems by identifying governance actors without having to select them a priori, thus minimizing selection bias. The advantage of this approach is that the network emerging is not only composed of formal and informal actors involved in developing actions for sustainability, but also includes actors that produce knowledge about the city. In this way, the different ways of knowing and framing the system, which influence visions, are included as part of the governance analysis. The theoretical and methodological details of the KASA approach and SNA tools can be found elsewhere (Muñoz-Erickson 2012, 2014), but I summarized the SNA methods used to identify the central actors, which serve as the unit of analysis for analyzing visions. 


\section{METHODS}

To construct the overall network of actors involved in land use and green area governance in the city of San Juan, I gathered the data using a survey distributed in 2009 to 110 different organizations identified through a snowball sampling approach, including governmental, nongovernmental, academic, communities, and businesses working on or concerned with environmental, land use, and green area issues in the city (Bernard 2006). I followed the Ernstson et al. (2008) approach for defining a whole network, i.e., group, boundary using ego-network, i.e., individual, level information. The ego network approach uses a recall method in which participants list the organizations that they most frequently interact with to obtain knowledge and information about land use and green areas in the city. Sixty-three organizations responded (57\% response rate) and from their responses I calculated the frequencies for the all the organizations mentioned, selected the organizations mentioned at least twice, and built the overall network population of 26 organizations. Each of the 26 organizations became a separate node in the network, and each node is related or 'tied' to other nodes by the flow of knowledge and information (for the results of the overall network see MuñozErickson 2014). I identified (1) the central or powerful actors from the overall network using 'centrality' measures to calculate the number of links a node has as an indicator of dominance over information flow, i.e., centrality; (2) the number of unique groups only connected through that individual as an indicator of knowledge brokering, i.e., betweenness; and the nodes, which are linked with bidirectional ties, as an indicator of two-way interaction of knowledge flow, i.e., reciprocity (Brass and Burkhardt 1993). Eight central nodes resulted from the centrality analysis, and these became the actors I focused on to analyze visions, frames, and knowledge systems. For the purposes of the qualitative analysis, I added the Mayor's office as another central actor in the network given its powerful influence over the vision and planning of the city even though it did not emerge as a source of knowledge from the network analysis.

For the qualitative analysis, I used a 'grounded approach' to discourse analysis (Glaser and Strauss 1967, Hajer 2003), which allowed the visions and frames to emerge from the various ways that the central actors think, talk, and construct their understandings about the city and goals for the future. Data was collected, coded, and organized into categories that characterized future visions and frames. Specifically, I categorized how the urban system is bounded temporally and spatially, what dimensions of sustainability are being valued and prioritized, e.g., economic, social, environmental, and how the data interpret and address problems facing the city. Except for official plans or policies that express an explicit vision of the city, as is the case for the state and city visions I will show later, the visions reflected hidden values within the mission, goals, and activities of organizations following the discursive approach of interpretative policy analysis (Hajer 2003). To analyze actors' knowledge systems, I identified mayor epistemologies, i.e., disciplinary traditions and paradigms that inform conceptual and methodological practices for knowledge production, as well as the data, models, and technologies that organizations use to inform their decisions and activities (Miller et al. 2011a). Data for the discourse and knowledge system analysis were collected from official organizational documents, e.g., planning and governmental reports; key informant interviews; scientific products, e.g., articles, models, databases; websites; newspaper articles; as well as images, such as photos, maps, and plans.

\section{Context}

As the capital of Puerto Rico, San Juan is the island's political, cultural, and economic hub. The city is part of the San Juan Metropolitan Area (SJMA; Fig. 1) and contains the main governmental offices, commercial ports, financial centers, and tourism and consumer services for the island. The rapid economic development of Puerto Rico in general, and the city in particular, over the past 70 years serves as a development model for the Caribbean and beyond. Nevertheless, the quality of life in the city has deteriorated. The last census revealed that the city's population is declining and most of the social and economic indicators lag behind U.S. averages. Economic and social polarization is increasing, with rising gaps between rich and poor, high crime and drug-related problems (Puerto Rico Planning Board 2006). Increasing urban sprawl into the surrounding rural areas of the municipality has led to diminishing economic activity in urban cores (Seguinot-Barbosa 1996) and pressure on the remaining continuous forest cover at the headwaters of the city's main watershed (Ramos González et al. 2004).

Fig. 1. Map of Puerto Rico and the Caribbean (left panel), and the San Juan Metropolitan Area (SJMA) and the Municipality of San Juan (right panel). Source: Adapted from Ramos González et al. 2004.

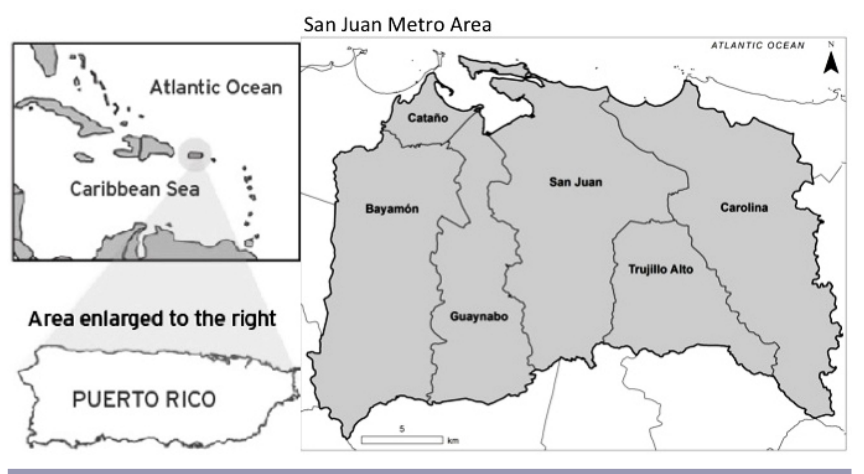

Because of its geography as a Caribbean coastal city, San Juan residents are already exposed to various hazards, such as hurricanes, tsunamis, and sea level rise. Land development practices, which lead to vegetation removal, stream modification, and soil erosion, have created an infrastructure that, in interaction with the hazards described, increases people's vulnerability to flooding and heat stress, for instance. Historically, land-use planning has been centralized and the state's main goal has been mainly economic development (Santana Rabell 1989). In 2002, the city began the decentralization process to become an autonomous municipality, and this involved developing the first comprehensive land-use plan for the city, what became the 2003 San Juan Municipality Territorial Ordinance Plan (TOP). San Juan, however, did not receive full autonomy until 2009; therefore the TOP wasn't effective until then. Thus, the state continued to have jurisdiction over land use and development permits. In addition, the implementation of KASA in 2009 revealed more visions coexisting for the city. 


\section{FINDINGS}

Four visions for the future of San Juan emerged from the analysis (Table 1): the Economically Sustainable City, the Livable City, the Modern City, and the Ecologically Sustainable City. The Economically Sustainable City is the dominant vision for the city as reflected in the goals of the state's main agencies regulating land-use planning and environmental issues in the city, i.e., PR Planning Board (PRPB), PR Environmental Quality Board, and the PR Department of Natural Resources, and the network's most central actors (see larger blue circles in Fig. 2). The state's plan is still under development but it outlines a general vision for Puerto Rico's development over the next 20 years, seeking to make the island competitive in a globalized world. The PRPB's main development strategy is the regionalization of key areas on the island based on their economic and social overlaps as well as particular strengths. As stated in a key instrument influencing the PRPB's goals and economic development strategy for Puerto Rico (Puerto Rico Planning Board 2010:9), “....the PRPB is now committed to a much more participative focus and a conviction that the market is the primary instrument for allocation of resources in an economy such as ours." Under this vision, San Juan is framed as the epicenter of the development of the San Juan Metropolitan Area region.

Fig. 2. Map of future urban visions of San Juan and central actors in the knowledge network. Detailed picture of the central actors in the knowledge network of San Juan and their future visions of the city. IITF: International Institute of Tropical Forestry; PB: Puerto Rico Planning Board; EQB: Puerto Rico Environmental Quality Board; DENR: Puerto Rico Department of the Environment and Natural Resources; UPR: University of Puerto Rico; CT: Conservation Trust; SJM: San Juan Municipality; SDI: Sustainable Development Institute; SCSJEC: Special Commission for the San Juan Ecological Corridor. Blue color indicates local or state agency, green color indicates local NGO, and purple color indicates research/academic institution. Circles with dash lines represent the different future visions that these actors share.

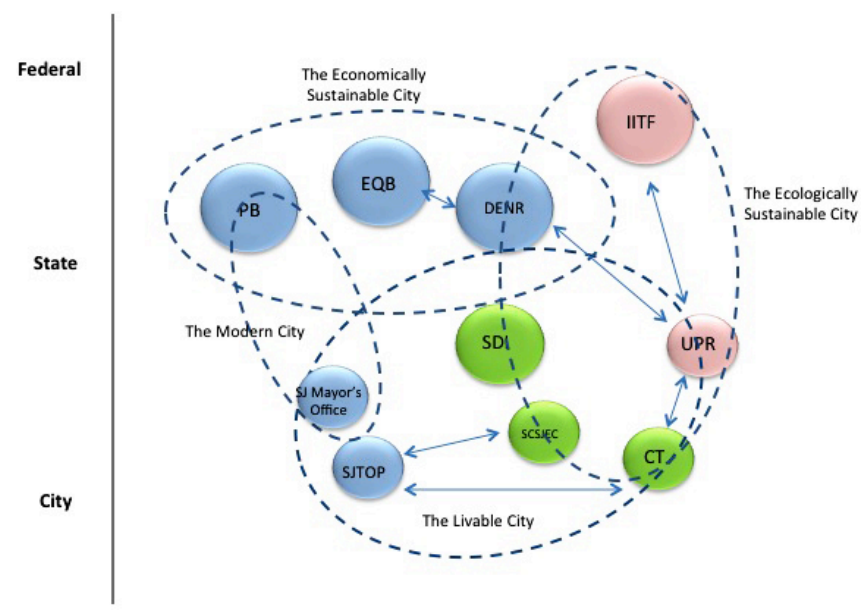

The vision of San Juan as a Modern City primarily reflects the goals of former Mayor Jorge A. Santini Padilla for the redevelopment and revitalization of San Juan's main urban cores. During his tenure from 2000 through 2012, Mayor Santini Padilla focused on these areas as places to invest to increase the visibility of the city, thus making San Juan a more 'wordly' city (San Juan Municipality 2007). A key emphasis of this vision is the revitalization, aesthetic and modern, of the municipality's existing infrastructure, such that it will be 'attractive' and 'new,' to promote financial investment and increased economic vitality. The time span for this vision is short, spanning about 20 years. Although a new mayor was recently elected and the continuation of these projects is in question, it is likely that this vision had a lasting influence on the identity of San Juan.

Alternative visions for the city place more emphasis on the marginal social and ecological values of San Juan. The Livable City vision reflects the goals and expectations of two main sectors of the city: the city government, through the TOP, and the civic sector, through the work of nongovernmental organizations (NGO) and community-based organizations. Specifically, the TOP states that it seeks to "recover the city, make it more livable and enjoyable to all its inhabitants and for all its inhabitants: a premier city, an efficient city, clear, orderly, safe, beautiful and that also serve those who inhabit it, especially those that have been marginalized" (San Juan Municipality Office of Planning and Territorial Ordinance 2003:11). This vision is framed as a change from previous unsustainable urban patterns, including urban sprawl, a deteriorating infrastructure, and diminishing green areas, to strategies of redevelopment, revitalization, and conservation of land resources, which would improve the current conditions for the collective society.

As the name suggests, the Ecologically Sustainable City vision strongly values the sustainability of the city's ecological systems. The specific vision has not been articulated by a particular institution or sector; rather, it emerged from the discourses and actions of the scientific community, environmentally minded NGOs, and community groups. Key ideas framing this vision are systems thinking, specifically the connectivity among ecological communities, e.g., forest corridors, ecological networks functioning at multiple spatial scales, and long-term processes to maintain and enhance the resilience of these systems from disturbance. As one ecologist from the University of Puerto Rico (UPR) expressed, the vision for San Juan is of a "city with a reduced ecological footprint, with great connectivity, and aesthetically pleasing."

The knowledge systems supporting these four visions in San Juan emphasize different epistemologies, practices, and technologies employed in the way that the city is 'seen' and 'known' by San Juan actors (Table 2). For instance, the state's knowledge system uses aggregated socioeconomic information in their plans, but lacks scientific analyses regarding the ecological functioning of the city or social data on justice issues crucial to a sustainable development strategy. The Modern City relies on a knowledge system developed by a Boston-based firm that strongly emphasizes modern technologies of visualization. These knowledge systems are characteristic of the technical rational common to governmental practices that rely on statistical measurements and technological tools to make society more simple and legible (Scott 1998). In addition, these knowledge systems are missing key spatial scales and elements of the socialecological system, such as watersheds as ecological units or the traditional 'barrios' as social communities, leaving out crucial 
Table 1. Summary of the characteristics of each vision for the future of San Juan.

\begin{tabular}{|c|c|c|c|c|}
\hline Elements of Vision Framing & $\begin{array}{l}\text { Economically Sustainable } \\
\text { City }\end{array}$ & Modern City & Ecologically Sustainable City & Livable City \\
\hline 1. Goals and values & $\begin{array}{l}\text { Economic growth for the } \\
\text { region and island }\end{array}$ & $\begin{array}{l}\text { Efficient and modern } \\
\text { infrastructure; economic } \\
\text { development; aesthetic } \\
\text { qualities }\end{array}$ & $\begin{array}{l}\text { Ecological health; ecological } \\
\text { footprint low }\end{array}$ & $\begin{array}{l}\text { Quality of life; vital and safe; } \\
\text { clean and green, i.e., } \\
\text { sustainable development }\end{array}$ \\
\hline 2. Overall strategies & $\begin{array}{l}\text { Economic investments; } \\
\text { promote tourism industry; } \\
\text { livable urbanism }\end{array}$ & $\begin{array}{l}\text { Revitalization and } \\
\text { redevelopment of urban } \\
\text { cores }\end{array}$ & $\begin{array}{l}\text { Restoration; protection of } \\
\text { watershed functions and } \\
\text { biodiversity; land } \\
\text { connectivity; increase green } \\
\text { areas }\end{array}$ & $\begin{array}{l}\text { Revitalization; } \\
\text { redevelopment; conservation } \\
\text { of natural areas }\end{array}$ \\
\hline 3. Spatial scale & Metropolitan area & Urban cores & $\begin{array}{l}\text { Watersheds and other } \\
\text { biophysical delineations, e.g., } \\
\text { coastal zones, ecological } \\
\text { corridors }\end{array}$ & Municipality \\
\hline 4. Temporal scale & 20 years & $\sim 20$ years & $\begin{array}{l}\text { Not articulated; depends on } \\
\text { long-term ecological renewal } \\
\text { processes }\end{array}$ & $\begin{array}{l}\text { Long term, but not } \\
\text { specifically identified in plan }\end{array}$ \\
\hline $\begin{array}{l}5 . \text { Procedure to generate } \\
\text { vision }\end{array}$ & $\begin{array}{l}\text { Expert consultation, } \\
\text { economic planning }\end{array}$ & $\begin{array}{l}\text { Expert consultation, } \\
\text { architecture/urban design }\end{array}$ & $\begin{array}{l}\text { Scientific research, } \\
\text { biophysical and ecological } \\
\text { sciences }\end{array}$ & $\begin{array}{l}\text { Consultative public } \\
\text { participation, community } \\
\text { boards and information social } \\
\text { networking among civic } \\
\text { groups }\end{array}$ \\
\hline
\end{tabular}

vulnerabilities affecting residents, i.e., increasing flood risks in the face of climate change.

Although the knowledge systems of the Ecologically Sustainable City can fill epistemological gaps related to ecological system dynamics, the traditional scientific and academic culture draws strong boundaries between different disciplines, e.g., natural vs. social sciences, and different institutional spheres, e.g., academia and policy, thus discouraging the type of transdisciplinary collaboration and knowledge pluralism necessary for addressing sustainability strategies (Wiek and Walter 2009, Miller et al. $2011 b$ ). As a result, the scientific community has not articulated a clear, shared vision for the future of the city. The Livable City vision attempts a more integrative approach to urban planning and sought a wider range of perspectives in its development, including consulting government experts, scientists, and citizens. Thus, although this vision relies also on traditional planning metrics, e.g., economic and social indicators, to some extent, the planning process was open to other rationales, including the local knowledge that citizens bring to the evaluation of policy-relevant knowledge. The civic sector, including residents, community organizations, and nongovernmental organizations, has had a large role in implementing on-the-ground initiatives that complement the Municipality's Territorial Ordinance Plan. The civic sector has also been instrumental in translating urban ecological and environmental science into visions and stewardship strategies throughout the city (Muñoz-Erickson 2012). Such civic initiatives make use of a large variety of popular, artistic, and social mediums to represent their knowledge and visions of the city. Increasingly, this civic knowledge system is adapting technologies from the scientific and planning communities, i.e., Geographic Information Systems (GIS) to represent their knowledge and increase its credibility in the planning and policy arena.

\section{DISCUSSION}

\section{Theoretical, methodological, and practical implications}

Competing frames of the urban social-ecological system The implementation of KASA in San Juan revealed that although sustainability is a concept found across all four visions, they each optimize distinct dimensions of the concept. None of the visions offers a pathway to sustainability that integrates economic, ecological, equity, and technical dimensions into a long-term development strategy for the city. The contrasts in these visions can be explained in part by the frames shaping the understanding, bounding, and perception of the system. For instance, the lack of attention by the dominant visions, i.e., the Economically Sustainable City and the Modern City, to multiple scales and social units in San Juan, e.g., communities and watersheds, results in crucial components of the system being left out. These dominant frames in San Juan have determined which natural and social qualities of society should receive greater priority in decision making at the expense of other less powerful frames.

The role of adaptive governance is therefore more complex than simply negotiating closure around a particular vision of sustainability. It is also about examining the role of frames, the criteria being used in bounding the social-ecological system, and the elements being rejected in the politics promoting particular pathways for sustainability (Smith and Stirling 2010). All of the visions and knowledge systems, or a combination of some, are necessary to address the complexity of San Juan's socialecological system. However, the spatial and institutional voids mentioned above, if left unexamined, can lead to competing strategies and solutions, and could possibly weaken the ability of institutions to respond and adapt to change at the scales in which the changes are likely to happen in the future (Olsson et al. 2007, Leach et al. 2010). As Hommels (2008) showed in her study of urban redevelopment in the Netherlands, reconciliation of 
Table 2. Summary of the knowledge systems supporting different visions in San Juan.

\begin{tabular}{|c|c|c|c|c|}
\hline $\begin{array}{l}\text { Knowledge system } \\
\text { element }\end{array}$ & $\begin{array}{l}\text { Economically Sustainable } \\
\text { City }\end{array}$ & Modern City & $\begin{array}{l}\text { Ecologically } \\
\text { Sustainable City }\end{array}$ & Livable City \\
\hline Mayor epistemology & $\begin{array}{l}\text { Economic planning; } \\
\text { technical rationality }\end{array}$ & $\begin{array}{l}\text { Architecture; urban } \\
\text { design; technical } \\
\text { rationality }\end{array}$ & $\begin{array}{l}\text { Natural sciences; ecology; } \\
\text { scientific rationality }\end{array}$ & $\begin{array}{l}\text { Economic and social planning; } \\
\text { social sciences; technical, scientific, } \\
\text { and cultural rationalities }\end{array}$ \\
\hline $\begin{array}{l}\text { Information and data } \\
\text { systems }\end{array}$ & $\begin{array}{l}\text { Quantitative data; } \\
\text { economic and social from } \\
\text { the Census and specific } \\
\text { economic studies }\end{array}$ & $\begin{array}{l}\text { Quantitative, qualitative, } \\
\text { visual information; } \\
\text { economic indicators } \\
\text { from other agencies }\end{array}$ & $\begin{array}{l}\text { Quantitative data; } \\
\text { hydrological, climatic, } \\
\text { biophysical data and other } \\
\text { ecosystem-based indicators }\end{array}$ & $\begin{array}{l}\text { Quantitative and qualitative data; } \\
\text { social, economic, and } \\
\text { environmental data from other } \\
\text { agencies, e.g., Census, } \\
\text { environmental impact reports; } \\
\text { community/neighborhood visits } \\
\text { and visual assessments }\end{array}$ \\
\hline $\begin{array}{l}\text { Practices and } \\
\text { technologies }\end{array}$ & $\begin{array}{l}\text { Cost-benefit analyses; } \\
\text { expert consultation; } \\
\text { economic models and } \\
\text { forecasts; GIS } \\
\text { technologies; land surveys }\end{array}$ & $\begin{array}{l}\text { Visualization and design } \\
\text { tools, e.g., AutoCad; } \\
\text { Google Sketch (3-D } \\
\text { rendering) }\end{array}$ & $\begin{array}{l}\text { Hypothetical-deductive } \\
\text { approaches; laboratory and } \\
\text { field experiments; resource } \\
\text { inventories; GIS; hypothesis } \\
\text { driven statistical, spatial, and } \\
\text { system models; peer-review } \\
\text { process }\end{array}$ & $\begin{array}{l}\text { Participatory planning; expert } \\
\text { consultations; contextual } \\
\text { knowledge; community board } \\
\text { meetings; GIS; social networking } \\
\text { mediums, e.g., Facebook, Twitter; } \\
\text { visual media, e.g., You Tube; direct } \\
\text { observations; cultural events }\end{array}$ \\
\hline
\end{tabular}

competing frames by city planners who were aware and explicitly managed these frames was necessary to overcome the institutional obduracy that was keeping actors from moving forward with urban renewal efforts.

Knowledge-power relationships and adaptive urban governance A complementary and inclusive knowledge-action system that precisely takes advantage of the diversity of knowledge systems in the actor network can be a useful tool for city administrators and managers to comprehend social-ecological dynamics at multiple scales. For instance, the multiple knowledge systems coexisting in San Juan could form a complementary and polycentric platform for understanding SES dynamics from various perspectives, including both technical and cultural rationalities. Similar to what Brand and Karvonen (2007) termed an "ecosystem of expertise," this platform can fill the various knowledge niches necessary to collectively choose appropriate pathways given the particular system context. The civic knowledge system emerging in San Juan, alongside scientific and other expert knowledge, has the potential to contribute contextual knowledge that is so crucial to understand how the city functions. To build urban adaptive capacity requires the inclusion of the civic and local knowledge that can only be acquired through experiencing and responding to the city as a result of people's daily living dynamics in the urban system (Scott 1998).

The importance of combining diverse knowledge systems as a social strategy to enhance learning and adaptive capacities has been well established by adaptive governance and innovation scholars (Folke et al. 2003, Reid et al. 2006, Westley et al. 2011, Klerkx et al. 2012, Wieczorek and Hekkert 2012). The case of San Juan, however, suggests that power asymmetries in the information network may serve as a barrier to combining different knowledge systems. Specifically, there is a knowledge hierarchy in which powerful actors perpetuate the conventional, dominant frames and knowledge systems of the city and create closure around a particular set of sustainability qualities, e.g., economic growth, for San Juan at the expense of alternative models, e.g., environmental and social. Although new visions, frames, and knowledges are emerging from San Juan's actor-network, these face the institutional inheritance of older ideas and ways of thinking in governance as described by Healey et al. (2003). Thus, power asymmetries in knowledge systems and networks could hamper the generation of new insights and potential to create conditions for adaptive governance in San Juan.

A crucial conceptual and methodological step in SES and adaptive governance research in cities is to expand the scope of how we define knowledge systems. Multiple epistemologies beyond ecology, public reasoning styles, and politics of expertise should be dimensions of this expanded definition. As Ernstson (2013) suggests, governance models for urban SES should shift definitions of knowledge from a purely functionalist perspective, i.e., the view that knowledge of different actors is merely seen as useful for building more complete understanding of ecosystem dynamics, to consider the situatedness of knowledge. In other words, knowledge and expertise should be considered as products of social practices, political struggles, and cultural processes. Much like the spatial boundaries surrounding system scales, knowledge systems have boundaries that define their power, credibility, and connectivity to other scopes of knowledge. Therefore, the level of fragmentation and connectivity among knowledge systems can affect the degree to which knowledge can be combined for learning and adaptation.

\section{Knowledge-action systems that foster adaptive and transformation capacities in cities}

How can knowledge-action systems be built to enhance the ability of decision makers and practitioners to facilitate adaptive and transformational capacity in cities? Addressing how visions of sustainability are emerging in cities has practical implications on how we design and evaluate knowledge-action systems to develop scenarios, strategies, and indicators for navigating sustainability pathways. Harnessing knowledge and technology to understand SES condition and change in light of future uncertainty should not be the only function of knowledge systems for sustainability. 
Knowledge-action systems must be able to also anticipate, manage, and address the politics that emerge as cities reconfigure themselves to address sustainability (Muñoz-Erickson 2014). Given that urban sustainability brings up many different issues to different people, knowledge-action systems will be most effective to the extent that they are linked to the complex political and cultural configurations of cities as SES. In addition, urban innovation can be stimulated through knowledge networking and coconstruction of frames (Ernstson et al. 2010).

As such, knowledge-action systems for San Juan, and cities in general, should be designed to bring together the plurality of actors, ways of knowing, and political expectations, which are becoming characteristic of urban systems. In addition to building credible and legitimate knowledge, knowledge-action systems should provide opportunities for authentic dialogue, epistemic pluralism, and reflexivity (Miller et al. 2011b, Muñoz-Erickson 2012). Deliberation is necessary to challenge basic assumptions of the status quo that keep ideas, institutions, and practices trapped in a particular pathway (Innes an Booher 2003). To stimulate pluralism and reflexivity on the part of all stakeholders, including analysts and scientists, social arenas in which actors can 'open up' and negotiate the epistemic dimensions of sustainability, such as whose knowledge counts and whose systems frame counts, are also crucial (Smith and Stirling 2010). The KASA approach has the potential to inform the design of knowledge-action systems, including specific institutional arrangements, such as joint knowledge production (Hegger et al. 2012) and boundary organizations (Guston 2001), by revealing the extent to which existing governance networks are obdurate or whether they allow alternative and innovative pathways to emerge in the city (Muñoz-Erickson 2014).

\section{CONCLUSION}

I have shown that visions or pathways to sustainability are more plural in practice and open to reformulation. We need to recognize the essentially political nature of sustainability and understand SES from multiple perspectives and ways of knowing. My approach and findings demonstrate the importance of disentangling the socio-political and cultural factors that may shape adaptive capacity within existing governance networks and institutional arrangements. Making visions explicit is necessary to evaluate alternative pathways in light of the uncertainty and surprises that future changes, such as climate change, will bring to the governance of SES. The political conditions for the kinds of negotiation and coordination necessary to evaluate and anticipate effects of different courses of action for sustainability can then become apparent (Smith and Stirling 2010).

The visions, however, are not fixed categories, but rather they are nonexclusive, such that an actor can hold several visions simultaneously or their visions can change over time. In other words, they are dynamic. Because my findings are limited to the governance conditions captured at a moment in time, future research is necessary to examine how dynamics and visions in the actor-networks change over time and how they relate to the capacity of the system to adapt to future change. Also, the findings are not meant to prescribe ideal sustainable strategies per se for San Juan or cities in general. An evaluation of the alignment of these visions with the biophysical and social realities of the city is beyond the scope of this study and a subject for future research.
Urban sustainability is not just defined by physical boundaries, but by socio-political boundaries as well. The value of the approach taken in this study is in the way in which it critically explores embedded ways of thinking and power structures at the very sites in which new ideas and pathways for the future are being produced, the knowledge-action systems. This approach is an essential element of urban adaptive capacity and can be applied to any city as a 'window' to anticipate governance dynamics and tensions that can potentially hamper emerging transformation and novelty. Understanding urbanites' future visions is crucial to deliberate sustainability problems, conduct sustainability science, and implement solutions or strategies for the future. Put differently, building adaptive capacity for a city will largely depend on understanding what a city means to its inhabitants, i.e., how they frame it, how they know it, and how they imagine it.

\section{Responses to this article can be read online at: http://www.ecologyandsociety.org/issues/responses. php/6457}

\section{Acknowledgments:}

I am grateful to Charles L. Redman, Clark Miller, Kelli L. Larson, Ariel E. Lugo, Mildred Alayón, and San Juan ULTRA colleagues for their guidance and review of this manuscript. This work was supported by the National Science Foundation under grant numbers 0948507 (Urban Long-Term Research Area Exploratory) and 0504248 (Integrative Graduate Education and Research Training). Any opinions, findings and conclusions, or recommendations expressed in this material are those of the author and do not necessarily reflect the views of the National Science Foundation $(N S F)$.

\section{LITERATURE CITED}

Bernard, H. R. 2006. Research methods in anthropology: qualitative and quantitative approaches. Altamira, Berkeley, California, USA.

Brand, R., and A. Karvonen. 2007. The ecosystem of expertise: complementary knowledges for sustainable development. Sustainability: Science, Practice, and Policy 3(1):21-31. [online] URL: http:///archives/vol3iss1/0601-004.brand.html

Brass, D. J., and M. E. Burkhardt. 1993. Potential power and power use: an investigation of structure and behavior. Academy of Management Journal 36(3):441-470. http://dx.doi.org/10.2307/256588

Brooks, N., W. N. Adger, and P. M. Kelly. 2005. The determinants of vulnerability and adaptive capacity at the national level and the implications for adaptation. Global Environmental Change 15:151-163. http://dx.doi.org/10.1016/j.gloenvcha.2004.12.006

Dietz, T., E. Ostrom, and P. C. Stern. 2003. The struggle to govern the commons. Science 302:1907-1912. http://dx.doi.org/10.1126/ science. 1091015

Ernstson, H. 2013. The social production of ecosystem services: a framework for studying environmental justice and ecological complexity in urbanized landscapes. Landscape and Urban Planning 109(1):7-17. http://dx.doi.org/10.1016/j.landurbplan.2012.10.005 
Ernstson, H., S. Sörlin, and T. Elmqvist. 2008. Social movements and ecosystem services - the role of social network structure in protecting and managing urban green areas in Stockholm. Ecology and Society 13(2): 39. [online] URL: http://www. ecologyandsociety.org/vol13/iss2/art39/

Ernstson, H., S. E. van der Leeuw, C. L. Redman, D. J. Meffert, G. Davis, C. Alfsen, and T. Elmqvist. 2010. Urban transitions: on urban resilience and human-dominated ecosystems. AMBIO 39 (8):531-545. http://dx.doi.org/10.1007/s13280-010-0081-9

Folke, C., J. Colding, and F. Berkes. 2003. Synthesis: building resilience and adaptive capacity in social-ecological systems. Pages 328-352 in F. Berkes, J. Colding, and C. Folke, editors. Navigating social-ecological systems: building resilience for complexity and change. Cambridge University Press, Cambridge, UK. http://dx.doi.org/10.1017/CBO9780511541957.020

Folke, C., T. Hahn, P. Olsson, and J. Norberg. 2005. Adaptive governance of social-ecological systems. Annual Review of Environment and Resources 30:441-473. http://dx.doi.org/10.1146/ annurev.energy.30.050504.144511

Glaser, B., and A. Strauss. 1967. The discovery of grounded theory: strategies for qualitative research. Aldine Transaction, Chicago, Illinois, USA.

Goffman, E. 1974. Frame analysis: an essay on the organization of experience. Harvard University Press, Cambridge, Massachusetts, USA.

Grimm, N. B., S. H. Faeth, N. E. Golubiewski, C. L. Redman, J. Wu, X. Bai, and J. M. Briggs. 2008. Global change and the ecology of cities. Science 319:756-760 http://dx.doi.org/10.1126/ science. 1150195

Guston, D. H. 2001. Boundary organizations in environmental policy and science: an introduction. Science, Technology, and Human Values 26(4):399-408. http://dx.doi.org/10.1177/0162243$\underline{90102600401}$

Hajer, M. 2003. A frame in the fields: policymaking and the reinvention of politics. Pages 88-113 in M. A. Hajer and $\mathrm{H}$. Wagenaar, editors. Deliberative policy analysis: understanding governance in the network society. Cambridge University Press, Cambridge, UK. http://dx.doi.org/10.1017/CBO9780511490934.005

Healey, P., C. de Magalhaes, A. Madanipour, and J. Pendlebury. 2003. Place, identity and local politics: analysing initiatives in deliberative governance. Pages 60-87 in M. A. Hajer and $\mathrm{H}$. Wagenaar, editors. Deliberative policy analysis: understanding governance in the network society. Cambridge University Press, Cambridge, UK. http://dx.doi.org/10.1017/CBO9780511490934.004

Hegger, D., M. Lamers, A. Van Zeijl-Rozema, and C. Cieperink. 2012. Conceptualising joint knowledge production in regional climate change adaptation projects: success conditions and levers for action. Environmental Science and Policy 18:52-65. http://dx. doi.org/10.1016/j.envsci.2012.01.002

Holling, C. S. 1973. Resilience and stability of ecological systems. Annual Review of Ecology, Evolution, and Systematics 4:1-23. http://dx.doi.org/10.1146/annurev.es.04.110173.000245

Hommels, A. 2008. Unbuilding cities: obduracy in urban sociotechnical change. MIT Press, Cambridge, Massachusetts, USA.
Innes, J. E., and D. E. Booher. 2003. Collaborative policymaking: governance through dialogue. Pages 33-59 in M. A. Hajer and $\mathrm{H}$. Wagenaar, editors. Deliberative policy analysis: understanding governance in the network society. Cambridge University Press, Cambridge, UK. http://dx.doi.org/10.1017/CBO9780511490934.003

Klerkx, L., M. Schut, C. Leeuwis, and C. Kilelu. 2012. Advances in knowledge brokering in the agricultural sector: towards innovation system facilitation. IDS Bulletin 43:53-60. http://dx. doi.org/10.1111/j.1759-5436.2012.00363.x

Leach, M. 2008. Pathways to sustainability in the forest? Misunderstood dynamics and the negotiation of knowledge, power, and policy. Environment and Planning A 40:1783-1795. http://dx.doi.org/10.1068/a40215

Leach, M., I. Scoones, and A. Stirling. 2010. Dynamic sustainabilities: technology, environment, social justice. Earthscan, London, UK.

Lugo, A. E. 2009. The emerging era of novel tropical forests. Biotropica 41(5):589-591. http://dx.doi.org/10.1111/ j.1744-7429.2009.00550.x

Miller, C., T. A. Muñoz-Erickson, and C. Monfreda. $2011 a$. Knowledge systems analysis: a report to the advancing conservation in a social context. Global Institute of Sustainability, Arizona State University, Tempe, Arizona, USA.

Miller, T. R., T. A. Muñoz-Erickson, and C. L. Redman. $2011 b$. Transforming knowledge for sustainability: towards more adaptive and engaged academic institutions. International Journal of Sustainability in Higher Education 12(2):177-192. http:dx.doi. org10.1108/14676371111118228

Moore, S. A. 2007. Alternative routes to the sustainable city: Austin, Curitiba, and Frankfurt. Lexington Books, Lanham, Maryland, USA.

Muñoz-Erickson, T. A. 2014. Co-production of knowledgeaction systems in urban sustainable governance: the KASA approach. Environmental Science and Policy 37:182-191. http:// dx.doi.org/10.1016/j.envsci.2013.09.014

Muñoz-Erickson, T. A. 2012. How cities think: knowledge-action systems analysis for urban sustainability in San Juan, Puerto Rico. Dissertation. School of Sustainability, Arizona State University, Tempe, Arizona, USA. [online] URL: http://repository.asu.edu/ attachments/94135/content//tmp/package-zUBFpT/

MunozErickson asu 0010E 11592.pdf

Olsson, P., C. Folke, V. Galaz, T. Hahn, and L. Schultz. 2007. Enhancing the fit through adaptive co-management: creating and maintaining bridging functions for matching scales in the Kristianstads Vattenrike Biosphere Reserve, Sweden. Ecology and Society 12(1): 28. [online] URL: http://www.ecologyandsociety. org/vol12/iss1/art28/

Olsson, P., L. H. Gunderson, S. R. Carpenter, P. Ryan, L. Lebel, C. Folke, and C. S. Holling. 2006. Shooting the rapids: navigating transitions to adaptive governance of social-ecological systems. Ecology and Society 11(1): 18. [online] URL: http://www. ecologyandsociety.org/vol11/iss1/art18/

Olsson, P., C. Folke, and T. Hahn. 2004. Social-ecological transformation for ecosystem management: the development of 
adaptive co-management of a wetland landscape in southern Sweden. Ecology and Society 9(4): 2. [online] URL: http://www. ecologyandsociety.org/vol9/iss4/art2/

Ostrom, E. 2009. A general framework for analyzing socialecological systems. Science 325(5939):419-422. http://dx.doi. org/10.1126/science.1172133

Pelling, M., and D. Manuel-Navarrate. 2011. From resilience to transformation: the adaptive cycle in two Mexican urban centers. Ecology and Society 16(2): 11. [online] URL: http://www. ecologyandsociety.org/vol16/iss2/art11/

Pickett, S. T. A., M. L. Cadenasso, J. M. Grove, P. M. Groffman, L. E. Band, C. G. Boone, G. S. Brush, W. R. Burch, Jr., C. S. B. Grimmond, J. Hom, J. C. Jenkins, N. L. Law, C. H. Nilon, R. V. Pouyat, K. Szlavecz, P. S. Warren, and M. A. Wilson. 2008. Beyond urban legends: an emerging framework of urban ecology as illustrated by the Baltimore ecosystem study. BioScience 58 (2):139-150. http://dx.doi.org/10.1641/B580208

Puerto Rico Planning Board. 2006. Plan de usos de terrenos de Puerto Rico. Borrador preliminar para vistas publicas. Puerto Rico Planning Board, Santurce, Puerto Rico.

Puerto Rico Planning Board. 2010. Comprehensive Economic Development Strategy: Puerto Rico. Puerto Rico Planning Board, Santurce, Puerto Rico. [online] URL: http://www.jp.gobierno.pr/ Portal JP/Portals/0/CEDS/CEDS $\% 20$ report aug $\% 2027-09 \% 20$ Version $\%$ 20final.pdf

Ramos González, O. M., C. D. Rodríguez Pedraza, A. E. Lugo, and B. Edwards. 2004. Forests and vegetation of the San Juan metropolitan area. International Insitute of Tropical Forestry, USDA Forest Service, Washington, D.C., USA.

Reid, W., F. Berkes, T. J. Wilbanks, and D. Capistrano. 2006. Bridging scales and knowledge systems: concepts and applications in ecosystem assessment. Island, Washington, D.C., USA.

San Juan Municipality Office of Planning and Territorial Ordinance. 2003. San Juan territorial ordinance plan: memorial, volume 3. San Juan Municipality Office of Planning and Territorial Ordinance, San Juan, Puerto Rico.

San Juan Municipality. 2007. Inversión billonaria para Río Piedras lleva a nivel residencial el sector. San Juan Municipality, San Juan, Puerto Rico.

Santana Rabell, L. 1989. Planificación y politica: un análisis crítico. Editorial Cultural, San Juan, Puerto Rico.

Scott, J. C. 1998. Seeing like a state: how certain schemes to improve the human condition have failed. Yale University Press, New Haven, Connecticut, USA.

Seguinot-Barbosa, J. S. 1996. The urban ecology of San Juan (a social geographic interpretation). (La ecología urbana de San Juan (una interpretación geografico social). Anales de Geografía de la Universidad Complutense. 16:161-184. Madrid.

Smit, B., and J. Wandel. 2006. Adaptation, adaptive capacity and vulnerability. Global Environmental Change 16:282-292. http://dx. doi.org/10.1016/j.gloenvcha.2006.03.008

Smith, A., and A. Stirling. 2010. The politics of social-ecological resilience and sustainable socio-technical transitions. Ecology and
Society 15(1): 11. [online]URL: http://www.ecologyandsociety. org/vol15/iss 1/art11/

Svendsen, E. S., and L. K. Campbell. 2008. Urban ecological stewardship: understanding the structure, function and network of community-based urban land management. Cities and the Environment 1(1):1-32. [online] URL: http://www.nrs.fs.fed.us/ pubs/3777

United Nations. 2007. World urbanization prospects: the 2007 revision population database. United Nations, New York, New York, USA. [online] URL: http://www.un.org/esa/population/ publications/wup2007/2007WUP_Highlights_web.pdf

Wasserman, S., and K. Faust. 1994. Social network analysis: methods and applications. Cambridge University Press, Cambridge, UK. http://dx.doi.org/10.1017/CBO9780511815478

Westley, F., P. Olsson, C. Folke, T. Homer-Dixon, H. Vredenburg, D. Loorbach, J. Thompson, M. Nilsson, E. Lambin, J. Sendzimir, B. Banerjee, V. Galaz, and S. van der Leeuw. 2011. Tipping toward sustainability: emerging pathways of transformation. $A M B I O$ 40:762-780. http://dx.doi.org/10.1007/s13280-011-0186-9

Wieczorek, A. J., and M. P. Hekkert. 2012. Systemic instruments for systemic innovation problems: a framework for policy makers and innovation scholars. Science and Public Policy 39:74-87. http://dx.doi.org/10.1093/scipol/scr008

Wiek, A., and D. Iwaniec. 2013. Quality criteria for visions and visioning in sustainability science. Sustainability Science April 2013. http://dx.doi.org/10.1007/s11625-013-0208-6

Wiek, A., and A. J. Walter. 2009. A transdisciplinary approach for formalized integrated planning and decision-making in complex systems. European Journal of Operational Research 197 (1):360-370. http://dx.doi.org/10.1016/j.ejor.2008.06.013 